\title{
SHARI'A STATE AND THE MAKING OF CHRISTIAN'S POLYPHONIC NARRATIONS IN CONTEMPORARY ACEH, INDONESIA
}

\author{
Yaser Amri* \& Muhammad Ansor \\ Institut Agama Islam Negeri Langsa \\ Jl. Meurandeh, Langsa Lama, Langsa, Aceh, Indonesia, 24415 \\ e-mail: yaser.amri@gmail.com, ansor@iainlangsa.ac.id
}

\begin{abstract}
There is an increasing interest in the study of Christian identity as a minority in a Muslim majority country. However, the study of plurality regarding the Christian identity considering the context of Islamic Sharia in Aceh is still limited. This article discusses the formation and representation of Christian identity in Aceh by focusing on how they negotiate internal aspirations in the context of Islamic Sharia. The data are based on in-depth interviews with fifteen Christian figures consisting of priests and religious leaders in five districts/cities in Aceh. The article argues that the internal and external dynamics of Christians influenced the narration of their identity in Aceh. The article shows the context of Islamic Sharia and the plurality of Christian internal aspirations resulting in unsimplifiable to a single genre, but rather polyphonic and sometimes mutually contested.
\end{abstract}

Keywords: Aceh Christian, identity reproduction, sharia law

* Corresponding Author 


\section{Introduction}

This article discusses the dynamics of Christian identity after the implementation of Islamic law in Aceh, Indonesia. The paper argues that the narrative of Christian identity needs to be understood as intersection between each individual and his social environment that makes the existence of Christians in Aceh is problematic to generalize in one particular identity genre. Identity is something fluid and dynamic. ${ }^{1}$ The structure, experience of locality, and social relations in the context of each community always influence the formation and representation of identity or vice versa. ${ }^{2}$ The Christians in Aceh are not only heterogeneous but sometimes contest each other in the articulation of a collective identity in a public sphere dominated by an Islamic identity.

So far, studies on this subject have seen Christians in Aceh as a homogeneous entity. ${ }^{3}$ They are represented as a minority religious group. Christian heterogeneity has not been adequately explored. The concept of the minority within a minority has received little attention from scholars. Policymakers also often ignore this diversity. Such point of view, among others, is shown by Miswari, ${ }^{4}$ Safrilsyah, ${ }^{5}$ Mawardi, Yusmami, Muhammad Suhaili Sufyan and Azwir. ${ }^{6}$ In other words, the dynamics of scholarship on Christians in Aceh do not take into account the ongoing social developments and transformations. By exploring the expression of the identity of Acehnese Christians based on the concept of polyphonic narratives, this paper intends to show what Michael Buehler and Dani Muhtada formulated as the diffusion of the Sharia law as part of the democratization process that takes place in Muslim-majority societies. ${ }^{7}$

This article challenges the view of Christian homogeneity and then considers two things that might influence the formation 
of their identity. First, this paper explores the influence of various internal dynamics on the articulation of Christian identity. Second, by highlighting the contribution of external factors to their opportunities to obtain permits for worship places, this paper reveals the contestation and diversity of identities within Christians. This paper reinforces previous scholarship that states that the formation of the identity of the Christian minority community in Aceh is an ongoing process so that it is difficult to simplify it in one particular identity genre. ${ }^{8}$

The intersection of identity and structure has received a lot of attention from academics. ${ }^{9}$ The dynamics of the formation of Christian minority identity are discussed by Mohanna Hadad, ${ }^{10}$ Julia Droeber, ${ }^{11}$ and Geraldine Chatelard, ${ }^{12}$ in the study of the production of Christian identity in the context of Arab culture in Jordan. Loren D. Lybarger discusses the contestation between nationalism and religion in influencing the identity of Christians in Palestine. ${ }^{13}$ The study shows the intersection between the social context and the formation of Christian minority identity. The dynamics of Christian identity related to structural relations have begun to get the attention of researchers, ${ }^{14}$ although it has not explored the diversity of voices and internal Christian contestations.

In discussing the narrative of Acehnese Christian identity, this article uses Mikhail Bakhtin's polyphonic concept. ${ }^{15}$ Bakhtin uses the polyphonic concept to describe the diversity of voices in literary texts. According to Bakhtin, texts always have multiple meanings and are polyphonic. ${ }^{16}$ Every reader has a right to create meanings of a text. ${ }^{17}$ The meanings of a text are something dynamic. In essence, Mikhail's polyphonic concept emphasizes the authority of the reader in creating various kinds of meanings of a particular text. ${ }^{18}$ In this paper, the author uses the concept of polyphonic to explore the diversity of strategies or ways in 
which Christians respond to their social environment which is dominated by Islamic Sharia narratives.

Civilization, culture, or tradition is a text in a broad sense. ${ }^{19}$ Aceh's Islamic civilization is a text in a broad sense. Christians in Aceh can be illustrated as 'readers' who are always in the process of creating meaning. They have the capability and freedom to form their identity and representation even though they cannot negate the influence of the surrounding social context. ${ }^{20}$ In line with the polyphonic concept, their reading of the text of Aceh's "Islamic Shari'a civilization" gave rise to diverse, nuanced voices and formed a harmonious rhythm in constructing and representing Christian identity in Aceh's public sphere. The differences in identity and aspirations within Christians ultimately create a harmonious, nuanced, polyphonic, and sometimes contestation appearance as a form of articulation of democracy and the diffusion of sharia law in Aceh.

\section{Methodology}

The data presented in this article were mostly collected during the year 2013 up to 2017 and updated in the year 2020 up to 2021. Since both authors reside in Aceh, the social dynamics of Christians in the research area have always been a relatively intensive concern. During the field data collection, the author met some Christian leaders, either pastors, priests, or church administrators in five respective districts/cities in Aceh, namely Langsa, Banda Aceh, Aceh Singkil, Aceh Tenggara, and Lhokseumawe. Conversations with them cover various topics and often extend beyond the main research topic. 
Table 1 Research Participant Profile

\begin{tabular}{lccccc}
$\begin{array}{l}\text { City/ } \\
\text { Categories }\end{array}$ & $\begin{array}{c}\text { Langsa } \\
\text { Banda } \\
\text { Aceh }\end{array}$ & $\begin{array}{c}\text { Aceh } \\
\text { Singkil }\end{array}$ & $\begin{array}{c}\text { Aceh } \\
\text { Tenggara }\end{array}$ & Lhokseumawe \\
\hline Priest & 2 & 4 & 1 & 1 & 1 \\
Pastor & 0 & 1 & 0 & 1 & 0 \\
Catholic figures & 0 & 0 & 0 & 0 & 0 \\
Protestant figures & 4 & 0 & 1 & 0 & 0 \\
\hline
\end{tabular}

Source: Field note, 2013-2017.

Material data were collected through observation and indepth interviews with fifteen (15) Christians and Catholic figures, consisting of nine priests, two pastors, and four church administrators that spread over the research area. Thirteen out of fifteen informants were male, and only two were female. Eight of them are local natives, while the other seven are from outside the province of Aceh. However, at the time of the interview, they had generally served in Aceh for more than three years. The majority of them are of Batak ethnicity, one is Chinese, and three are from Eastern Indonesia. The author recorded each interview with the informant's permission and stated that the information was part of the published research.

Data were analyzed with the workflows suggested by Miles and Huberman, ${ }^{21}$ namely, the reduction of data, presentation of data, and the presentation of conclusion. The author transcribed the interview that lasted between 60 to 120 minutes. The transcriptions are read repeatedly, categorized accordingly to the theme of the article, and then presented using descriptive, comparative, and discursive techniques. For the convenience of the informants, the author disguises the names, the affiliation, the origin of the district/city, or information related to the informants' privacy. 


\section{Results and Discussion Historical Review of Christian in Aceh}

The Christian population in Aceh, based on the population census about a decade ago, was 53 thousand people, or about one percent of the total population of Aceh province out of $4,494,410$ people. ${ }^{22}$ There is no current data that can be officially referred, to describe the Christian population. It is interesting to note that the populace in 2010 was not much different from the condition of the previous three decades. Mubarok reported that in 1992/1993, the Christian population in Aceh was around 51 thousand. ${ }^{23}$ It means there has been an increase of about two thousand people in the last three decades.

Geographically, the concentration of the Christian population is in Aceh Tenggara and Aceh Singkil. The Christian population in Aceh Tenggara makes up almost 20 percent (33,000 people) of the district's total population. ${ }^{24}$ Their population counted the majority in two sub-districts in Aceh Tenggara, namely Babul Makmur and Lawe Sigala-gala sub-districts. ${ }^{25}$ In Aceh Singkil, the Christian population makes up 10 percent (11 thousand people) of the district's total population. Simpang Kanan and Danau Paris are two sub-districts in Aceh Singkil with a significant Christian population, though not a majority.

The Christian population in Banda Aceh ranks third, at around two thousand. This figure is far from the conditions in Aceh Tenggara and Aceh Singkil. The distribution of Christians in other areas in Aceh is relatively small in number, around a thousand people, hundreds of people, or even only tens of people per district/city. Based on data released by Aceh's Central Bureau of Statistics (Badan Pusat Statistik, BPS) in 2010, the three regions with the smallest Christian populations are as follows: Pidie Jaya (15 people), Aceh Barat Daya (28 people), 
and Aceh Timur (39 people). As a reminder, the same source records the Christian population in Langsa at around 545 people. However, in 2020 it is assured that the Christian population in Langsa will increase significantly to more than a thousand if the number of students at Samudera Langsa University who are Christians is taken into account.

That the Christian population in Aceh has been relatively stagnant for nearly the last 30 years is puzzling. Because these numbers indicate the ratio of natality (births and deaths), and migration of Christians (from and to Aceh/Islam) over the last three decades, has been in a balanced manner. Agus Indiyanto's analysis is quite useful in curating the mystery of the stagnation of Aceh's Christian population. According to him, the analysis of population based on religion is not merely relied on figures, but also by considering the research methodology on which certain figures are obtained. The definition of religion in each research also needs to be scrutinized because it affects the final figures obtained. ${ }^{26}$

The stagnation of Aceh's Christian population indicates the inaccuracy of rumors of large-scale Christianization in Aceh. As a matter of fact, tensions in religious relations in Aceh in the last few decades have been triggered also by rumors of Christianization. ${ }^{27}$ The Deputy Governor of Aceh for the 20072012 period, Muhammad Nazar, once estimated that there would be 20,000 Muslims converting to Christianity. ${ }^{28}$ Although the details of this data have never been published, the narrative of Christianization is a latent problem in Acehnese society. Looking at the stagnation of this figure, it can be estimated that the dynamics of religious conversion from Islam to Christianity in Aceh (which is inaccurately described as Christianization), is not as much as it is described. 
The relationship between Christianity and Islam in Aceh is often mutually antagonistic. Suspicion and feelings of mutual threat have always colored the historical dynamics of the two communities. According to Mujiburrahman, this phenomenon is a portrait of Muslim and Christian relations in Indonesia during the New Order era. ${ }^{29}$ Feelings of mutual threat are represented in two terms that are quite popular in contemporary Indonesia: Christianization and Islamization. ${ }^{30}$ Fatima Hussein highlighted the roots of tension in relations between Muslims and Christians in Indonesia by discussing the influence of inclusive and exclusive understanding among Muslims. ${ }^{31}$ Unlike Hussein, Sumanto Al-Qurtubi assessed that the root of the tension did not only come from Islam but also from Christianity. ${ }^{32}$

The tension between Muslims and Christians in Aceh cannot be separated from the history of the Christian advent. ${ }^{33}$ The Christian missionaries present in Aceh along with the colonials since the 16th century AD (by the Portuguese) and culminated with the arrival of the Dutch in the 19th century AD. ${ }^{34}$ As written by Karel Steenbrink and Jan Sihar Aritonang, after the conquest of the kingdom of Malacca by the Portuguese, the kingdom of Aceh not only succeeded in taking over the role of Malacca as a trading center in the region but also sporadically attacked the center of Portuguese power in Malacca, although these efforts were never significantly successful. ${ }^{35}$

According to Amirul Hadi, in responding to the presence of colonialism, the Kingdom of Aceh was recorded as one of the most persistent in inciting resistance with the slogan of the religion. ${ }^{36}$ Islam is a source of energy for the Acehnese resistance. The Sabil War inflamed Aceh in the 17th century AD when expelling the Portuguese, ${ }^{37}$ and by the 20th century AD (18731903), the Dutch. ${ }^{38}$ The Aceh War was known as one of the biggest wars in the archipelago during the colonial period. ${ }^{39}$ 
The War of Aceh determined the color of Aceh's identity in the future. ${ }^{40}$ Imagination about Christianity as a social entity identical to colonialism is periodically transmitted in the memory of the Acehnese. A number of folk tales were compiled by Acehnese scholars and writers to perpetuate the story of the heroism of the Acehnese. Dokarim, an Acehnese writer, wrote Hikayat Prang Goumpeuni, to perpetuate the story of the Acehnese resistance to the Dutch. ${ }^{41}$ Ibrahim Alfian discusses various versions of war literature circulating in Acehnese society. These stories are arranged as a mechanism to awaken the spirit as well as perpetuate the heroism of the Acehnese. ${ }^{42}$

The Epic of the Sabil War, for some Acehnese people, is not only a symbol of heroism but also a mechanism for maintaining Aceh's Islamic collective identity and the feeling of being threatened by the existence of non-Muslims. The retelling and reciting of the Sabil War poems in several places during the war, which continues to this day, is a form of perpetuating this perspective. In line with that, Arskal Salim assessed that the construction of colonialism, which is identical to Christianity, contributes a negative framing of Christians to the mind of Acehnese people. ${ }^{43}$

The feeling of being threatened continues when contact between Muslims and Christians has intensified in Aceh. For example, the flow of foreign funds from non-Muslim donors to Aceh as part of the post-Tsunami reconstruction and rehabilitation efforts. Although all assistance from donors, who are predominantly non-Muslim, is openly accepted, suspicion of foreigners remains at the forefront. They suspect the aid contains a Christianization mission. They protect their community from non-Muslim movements, especially Christians. ${ }^{44}$ Islamic law and regulations prepared as a structural and cultural mechanism in preventing the expansion of Christianity in Aceh. 
Reed Taylor discusses the feelings of being threatened by Christians that the Acehnese had at that time. Taylor described the social changes that occurred in Acehnese society after the coming of NGOs (Non-Governmental Organizations) from various countries following the tsunami disaster. Even though their presence has had a positive impact on accelerating the rehabilitation of Aceh, the fact that the majority of these NGOs are nonMuslims became problematic for the Acehnese people. Informants interviewed by Taylor expressed apprehensiveness that NGO activists were secretly carrying out a Christianization mission. The people who do not have a sufficient understanding of Islam feared to be attracted to Christianity introduced by international NGOs. It is a real threat since some local people found converted to Christianity. ${ }^{45}$

To provide an understanding of the social context underlying the commentary of Taylor's informant, it should be pointed out that rumors of Christianity are a prominent discussion topic in Aceh. Khairil Miswar described the Christian missionary project after the Tsunami disaster as a real threat to the Islamic faith of the Acehnese. ${ }^{46}$ Taylor wrote that a few days before arriving in Banda Aceh, he received information about a foreign NGO that was deported from Aceh for being accused of carrying out a Christianization mission behind the social assistance project carried out. ${ }^{47}$ They could not clarify the allegation of forcing a local woman to convert to Christianity due to the limited space available for clarification. Apart from that, the Islamic law and regulations in Aceh and Indonesia do regulate sanctions against people who propagate certain religions to adherents of other beliefs. ${ }^{48}$

The diversity of the historical social dynamics of Christianity in Aceh during the colonial period had an impact on the pattern of social relations between the two communities in modern 
Indonesia. The relationship between Christians and Muslims in Aceh, in other words, is a result of the past. Likewise, the socio-cultural, historical, and local political contexts shape the relatively nuanced relations between Muslims and Christians in various places in Aceh. ${ }^{49}$ These dynamics are further discussed in the next sub-chapter of this article by emphasizing their influence on the formation and representation of Christian identity in Aceh.

\section{Polyphonic Narrative of The Christian in Aceh}

Christians in Indonesia are heterogeneous entities. ${ }^{50}$ So do the Christians in Aceh. Their aspirations and voices are polyphonic and sometimes mutually contested. The diversity of spiritual aspects, social conditions, economic backgrounds, and political aspirations makes Christianity difficult to put into one genre. This section explores the polyphonic Christian narrative in Aceh by linking it to the local context of Islamic law, Indonesian national dynamics, and transformation at the global level.

For general information, although the title of this article uses the term "Christian", the scope of the discussion includes Catholics and Protestants (the latter group being identified with Christians). The Protestant population in Aceh reaches 50 thousand people, while Catholics number around 3 thousand people. Although a statistical minority, the condition of the Catholic community in the research area is relatively stable. Two informants lead a Catholic church. The management of the church is integrated with primary and secondary education institutions. It is well known that Catholicism has a neat and hierarchical organizational system. The Catholic Church in Aceh has a strict hierarchy with the Indonesian Bishops Conference (Konferensi Waligereja Indonesia, KWI), as well as at the world 
level (Vatican). This condition, as will be discussed, affects the process of their identification and representation in Aceh's public sphere.

It has been mentioned that Protestantism in Aceh has various typologies. To facilitate the discussion of Christian dynamics in Aceh, the author follows the steps of Chang-You Hoon, who divides Christianity in Indonesia into three main streams; Ecumenical, Evangelical, and Pentecostal. ${ }^{51}$ However, Hoon's categorization has limitations when applied to Christians in Aceh. The grouping of the Evangelical and Pentecostal communities into a single genre is one of the minor modifications made to explore the dynamics of Christians in Aceh.

Ecumenical Christians are often classified as liberal Christians. This group is a mainstream Christian who values the reformist Calvinist and Lutheran traditions. ${ }^{52}$ This group is represented in the PGI (Persekutuan Gereja-gereja di Indonesia or Indonesian Church Association); a socio-religious organization (similar to Nahdhatul Ulama or Muhammadiyah) that houses most of the denominations in Indonesia outside of Evangelical and Pentecostal Christians. Their membership includes tribal churches, such as the Batak church, the Javanese church, the Maluku church, the Papuan church, and the like. Based on the type of church where they are affiliated, ten of the informants of this research are classified as Ecumenical Christians.

Evangelical Christians are a conservative church group that in Indonesia is under the umbrella of the PII (Indonesian Evangelical Fellowship or Persekutuan Injil Indonesia) or PGLII (Association of Churches and Evangelical Institutions of Indonesia or Persekutuan Gereja-gereja dan Lembaga-lembaga Injili Indonesia). The Evangelical movement is characterized by the mission of evangelism as the main orientation and the belief that the way of salvation is only obtained by those who follow the path of 
Jesus. ${ }^{53}$ According to Aritonang and Steenbrik,$^{54}$ the term Evangelical usually refers to conservative church groups in Indonesia who associate themselves as part of the fundamentalist movement that emerged in America in the early 20th century AD. One informant of this research is a member of Evangelical Christian.

The third, namely Pentecostal Christianity or commonly called Pentecostal-Charismatic is a branch of the church movement that focuses on the mission of the holy spirit, miracles, healing, or particular spiritual experiences. ${ }^{55}$ In Indonesia, Pentecostal Christians take shelter in the PGPI organization (Association of Indonesian Pentecostal Churches or Persekutuan Gereja-gereja Pentakosta Indonesia). It is estimated that there are hundreds of Pentecostal-Charismatic 'churches' in Indonesia scattered in several hotels, shopping centers, meeting rooms, or privately owned buildings such as houses or shophouses. ${ }^{56}$ Two of the informants are Pentecostal Christian leaders who organized worship activities at the shophouse before being sealed by the local government.

This study finds the diversity of views of Christians in Aceh in responding to socio-religious problems. For example, informants who are affiliated with Pentecostal Christians show different orientations and views from Ecumenical Christians regarding the strategy of indigenizing the Bible in the Veranda of Mecca. Pentecostals have an understanding that salvation can only be achieved through the way of Christ. Therefore, in an attempt to ensure that people find a way of salvation, they are trying to expand the number of their members. Pentecostals seem to pay less attention to the boundaries and code of ethics for the spread of Christian missions. Therefore, this group, as said by Hoon, is not only troublesome for Muslims, ${ }^{57}$ but also within Christian denominations since they tend to absorb members from other churches to expand the number of their members. 
In the case of Langsa, the ban of Indonesian Bethel Church (GBI, Gereja Bethel Indonesia) congregation was carried out because of local Muslim concerns about the expansion of GBI's membership. ${ }^{58}$ Internally, in the view of Christian in the Langsa themselves, the presence of GBI congregation is somewhat worrying because so far it has been proven that members from other churches shift to GBI. Similarly, in the case in Banda Aceh, the conflict between Muslims and GBI was because they were accused of spreading the Christianization mission which was carried out stealthily. ${ }^{59}$ To the author, informants GBI from Langsa and Banda Aceh expressed their refutation to this assumption. $\mathrm{NI}$, the pastor of GBI in Banda Aceh said that so far, not a single resident has converted to GBI. Similarly, GBI in Langsa said that the new members come from people outside the Acehnese ethnicity. However, a leader of GBI does not deny that one day he dreams of establishing a Pentecostal church in Aceh.

In contrast to Pentecostal Christianity, Ecumenical Christianity does not show any orientation to expanding membership. DM, a pastor of GPIB (Gereja Protestan di Indonesia bagian Barat or Protestant Church in Western Indonesia), admitted that he did not mind if his members wanted to move to another church. DM does not see conversion from one church to another as a sign that one is truer than the other. For him, there are many paths to salvation. All religions provide a way of salvation. To the author, DM said that once a Muslim visited him expressed an interest in converting to Christianity. To him, DM conveyed that he should first go deep into Islam before continuing with the intention of converting. In the end, the Muslim canceled his plan to convert to Christianity.

Two Catholic leaders said that in the past, Catholics had adhered to a doctrine that the path of Jesus is the only way to salvation. But that view has been corrected. Catholics believe 
that one can achieve salvation either through Catholicism or other religions. LI, a member of the Catholic church in Aceh Tenggara said that she still maintains a good relationship with the church even though she has already converted to Islam. $\mathrm{CH}$, the head of the Catholic church, said that once he had accompanied a member of his congregation who changed church affiliation to Protestantism due to marriage. On the other hand, $\mathrm{CH}$ does not mind if someone from another religion converts to Catholicism. A Muslim woman who converted to Catholicism told the author that Pastor $\mathrm{CH}$ trusted her to teach Catholic religious subjects.

The heterogeneity of Christian voices is apparent in the doctrines and rituals of worship. ${ }^{60}$ An informant from Pentecostal Christian in Langsa told the author that he moved from HKBP to GBI was because of the convenience he got from his new church. In terms of food, for example, he is more comfortable with the slaughtering rules in GBI. Another GBI figure told that he could not accept the local government's offer to join the HKBP in worship because he was not convenient with the method, both for linguistic and liturgical reasons.

Ecumenical Christian churches generally adopt a more traditional liturgical model than Pentecostal Christian churches. After several times observing the worship activities of an ecumenical church, the author finds the situation serene, calm, and traditional. No church music is sung cheerfully. On the other hand, while observing the worship activities of the Pentecostal church twice, the author witnessed an improvised, non-structuralist style of worship, oriented towards pragmatic goal achievement, and accompanied by happy or sad melancholy music. Some studies also inform that Pentecostal worship is sometimes integrated with healing purposes. ${ }^{61}$ 
The appearance of the clothes of the choir and dance participants is relatively similar to that of pop music performances. ${ }^{62}$ In line with Linda van de Kamp's findings, ${ }^{63}$ the close relationship between congregation members also makes the moment of worship at the Pentecostal Christian church different from the Ecumenical church. Likewise, the nuances of the worship of the Pentecostal Christian church look more emotional than what the author witnessed in the Ecumenical Christian church. In essence, the practice of worship in the Pentecostal Christian church shows improvisation and is responsive to the demands of modernity in religion. ${ }^{64}$

\section{One Christianity various church}

Not all churches in Aceh have permits as places of worship. Differences in access and opportunities of Christians regarding permit and the availability of places of worship affect how identity is constructed and represented. This session explores the identification of church leaders by considering the permit status of the church to which it is affiliated.

The discourse on places of worship is a crucial instrument to see the position of non-Muslims in the arena of Aceh's Islamic law. As the expert said, in areas where Islam is placed as the cornerstone for regulating the national system and orders, licensing for non-Muslims to build houses of worship is an important instrument to identify the level of inclusiveness or exclusivity of Muslim rulers. ${ }^{65}$ In line with that, the formation and representation of Christian identity in the work area of this research are also influenced by their opportunities and limitations in obtaining permits.

Aceh, after the implementation of Islamic law, issued regulations that were stricter than the national provisions in licensing the 
construction of places of worship. The regulation on the construction of places of worship for non-Muslims in Aceh refers to Qanun No. 4/2016. This regulation is an extension of the Aceh Governor's Regulation (Pergub) No. 25/2007. The provisions for the construction of houses of worship in Indonesia are regulated in PBM No. 9/ 2006 and 8/2006 concerning the construction of houses of worship for all religious adherents. ${ }^{66}$

The regulation on licensing of places of worship in Aceh has sparked conflict due to two things: (a) strict requirements restrictions that go beyond nationally stipulated regulations; (b) the application of the regulation is discriminatory because it only aimed at non-Muslims. The construction of houses of worship for Muslims is exempt from the provisions and conditions stipulated in the regulation. The Head of the Islamic Sharia Service (DSI, Dinas Syariat Islam) and the Head of Nation and Political Unity Body (Badan Kesatuan Bangsa dan Politik), at one of the research locations that the authors interviewed, assessed that the limitation of space for the construction of houses of worship for non-Muslims was a normal thing since Aceh had the privilege of implementing Islamic law. Meanwhile, supporters of the discourse on tolerance and religious freedom thought that the issuance of the qanun is a form of articulation of intolerance to non-Muslims in the name of Islamic law. ${ }^{67}$

Some scholars and religious freedom activists questioned the issuance of qanun 4/2016 because the requirements set were too heavy, that is a minimum of 140 users of houses of worship and 110 supporters from Muslims in the vicinity. This figure is indeed lower than the Aceh Governor Regulation No. 25/2007 which states a minimum requirement of 150 users and 120 supporters from local residents. Both qanun No. 4/2016 or Aceh Governor Regulation No. 25/2007 stipulates a higher requirement than the national regulation which only requires 
90 users and 60 supporters. Regardless of the number required, from the beginning, it has been the target of protests by scholars and religious freedom activists. ${ }^{68}$

The author met with church leaders, licensed churches as well as unlicensed. Based on the discussion, it is known that the status of ownership of permits for houses of worship affects how they represent their identity and assess the implementation of Aceh's Islamic law. They are categorized into at least three kinds: (a) church leaders whose church has permit letter, (2) church leaders whose church has permit letter but also look after or foster churches that do not have permits, and (3) church leaders whose church do not have a permit letter. All the leaders of the Pentecostal and Evangelical churches who were participants in this research had problems with the permit of places of worship. A few informants from the third category of church leaders were met by the author when their houses of worship had been sealed by the local government. One of the churches had their congregation disbanded after the interview took place.

Field data found that church leaders who already have permits generally understand or at least do not react aggressively to the church sealing policy by the local government. They behave as such because the sealed church was not under their responsibility. The leader of the HKBP in Langsa, which has a permit letter, did not show any objections when another church in the same area (GBI) was sealed by the government. PR, one of the leaders of the HKB told that the origin of the GBI congregation was registered in the HKBP, but then moved to the GBI.

The local government suggested that the HKBP admitted the GBI congregation for worship. HKBP leaders welcomed the proposal coldly. According to them, they are ready to accommodate the GBI congregation to perform worship at the HKBP church 
as long as they adjust to the protocol that has been going on as usual. As for the information, the Langsa government's offer for the GBI congregation to worship in the HKBP is an arbitrary recommendation and does not take into account the diversity of denominations within Christianity. But on the other hand, the cold response of the HKBP leadership also illustrates the lack of empathy for the problems experienced by the GBI congregation regarding the ban of their worship place.

A relatively similar response was also shown by the leadership of the GPIB when some churches in Banda Aceh were sealed by the local government. DM, the GPIB leader in Banda Aceh, admitted that he did not have sufficient authority to prevent the government from banning some churches that were not licensed. It is interesting to note that DM criticizes the phenomenon that occurs in the Christian environment in Banda Aceh where community leaders tend to divide by establishing new churches. DM suggested that church leaders and congregations who do not have permits integrate with churches that already have permits. DM also questioned the tendency of Christian leaders in their city to show less effort to build cross-church cooperation networks. DM, like other licensed church leaders in Aceh, is not interested in fighting for the church to get permission from the government.

The second category is the leaders whose churches are licensed but show aggressive protests over the actions of the local government to seal other churches. The Kuta Karangan Church has the status of a resort or leader of churches in the same fellowship in Aceh Singkil and surrounds. From 1979 to 2015, the conflict over housing in Aceh Singkil was a latent issue that periodically exploded into communal conflict. It was one of the biggest communal conflicts in 2012 and 2015, over houses of worship, in Aceh's modern history. In the 2015 incident, 
more than twenty houses of worship were banned and sealed by local authorities. Ten of them were later allowed to be used as places of worship, while about 10 churches were dismantled.

The author met BR, the pastor of the Kuta Karangan church in 2014, a year before the conflict in 2015 erupted. Based on an interview with BR, the author captures a high level of disappointment with the actions of the AS government that sealed several churches. According to him, this policy indicates that the local government is driven by a hard-line Islamic organization (FPI, the Islamic Defenders Front). The sealing was carried out a day after the demonstration by the city branch of the FPI. The author also met HM, the leader of FPI as well as the coordinator of the action, and found the fact that the local government did have a similar attitude to FPI: anxious about the existence of unlicensed churches. For the Aceh Singkil government, the FPI action is a source of social legitimacy to seal unlicensed churches.

According to BR, the conflict between Muslims and Christians in Aceh Singkil cannot be separated from the conflict that occurred in 1979. Some articles have discussed the conflicts over places of worship in the Aceh Singkil. ${ }^{69}$ Therefore, the author will not discuss more the details of these events. Suffice it to write here the construction and opinion of BR regarding the conflict. According to BR, the peace agreement in 1979 between Muslims and Christians in the form of an agreement for legally functioning one church and four undung-undung (a place of worship similar to a prayer room used as a place of worship for local Christians) did not take into account the development of the Christian population due to birth and migration factors. Therefore, according to him, this agreement needs to be revised again since the growth of Christians requires them to build new places of worship, in addition to the four 
churches that are already licensed. Later, about a year after the writer's meeting with BR, a communal conflict erupted. As already mentioned, peace between the two communities was restored after an agreement that about half of the sealed churches be allowed to operate and the rest dismantled.

The third model is church leaders whose churches are sealed by the local government. The author met with the leaders of four sealed churches. The four church leaders gave varied responses. Three church leaders reacted strongly in response to the sealing of their churches, while another was humble and accepted the policies of the local government. In addition, none of the churches that have been sealed off have their sealing status revoked.

Church leaders of GKKI (Gereja Kristen Kerasulan Indonesia or Indonesian Apostolic Christian Church) in Banda Aceh, and GBI of Banda Aceh and Langsa expressed resistance on different scales to the sealing by the local government. They are Pentecostal and Evangelical Christians. The support for religious freedom activists is also relatively strong for the community. Church leaders questioned the government's policy presume that they ignore the psychological condition of women and children. The government neglected the freedom of their congregation to practice their religion and belief. They admit that it is difficult to get permits because the requirements set are impossible to fulfill. But at the same time, they also hope that the government is willing to facilitate the provision of temporary houses of worship so that they can carry out worship activities and religious education for their communities.

At the time of data collection (2017), the authors found that although the government had officially closed the place of worship, the worship activities of the two churches did not stop, although they experienced significant obstacles. The GBI congregations in Langsa, both independently and with funding 
facilitation from the leadership, carry out worship activities in churches in the same denomination outside the province of Aceh. Sometimes they move around from house to house without the knowledge of the local government. Authors are allowed on several occasions to observe their religious activities.

The roots of the differences in attitudes between one church leader and another towards the sealing of the churches are interesting to discuss. This paper finds that the locality context and the characteristics of the leader figure and each community affect the presentation of identity and the attitude to the problems they face. MI, the leader of the GBI congregations, chose a strategy of resistance (although not openly) because she saw that her actions were an alternative that could be taken. She rejected the government's offer for her and her congregation to join a church that received official permission due to differences in doctrine and ritual procession. The HKBP is a tribal church that uses the Batak language as the medium of instruction in worship activities, while MI and its congregations who come from commonly non-Batak ethnic backgrounds do not understand the Batak language. To the author, MI admitted that she could not perform worship solemnly in such a condition that she did not understand the language of instruction used in the church. Meanwhile, IN, the head of Local church (PJKP PT. Arun) at Lhoksewmawe, admitted to accepting and understanding the local government's decision to ban worship activities at the church because he did not have a permit. IN was disappointed with the decision, but he accepted the government's decision with pleasure.

\section{Conclusions}

The above description has discussed the plurality of Christian identities in Aceh. Identity narratives are always in the process 
of being formed, dynamic, changing, and polyphonic. The article shows that the external factors in the form of the Acehnese Islamic narration on the one hand, and the internal dynamics of the Christian community itself on the other, influence the reproduction and presentation of identity. The diversity of social or political contexts and their respective experiences influence how social identity is presented in Aceh's public sphere.

This paper finds that Ecumenical Christians have relatively different experiences and challenges from Pentecostal or Evangelical Christians. The first model of Christianity tends to be more inclusive in the indigenization of the doctrine of Christ, less even-minded, and always tries to build horizontal relations with Muslims. The Pentecostal and Evangelical Christians have relatively different strategies in the indigenization of the doctrine of Christ. They believe that salvation is only available through the way of Christ, so evangelical missions tend to be oriented towards expanding membership and strengthening the vertical relationship between man and God. The diversity of internal dynamics ultimately affects the system of their social relations with the Muslim majority. Christians in Aceh appear in a polyphonic identity. This is not only a sign of the existence of a democratic process that develops in a society that is dominated by a single Islamic identity; also emphasized the recognition of the citizenship rights of non-Muslim minority communities.

Aceh's Islamic law and the social and demographic developments within Christianity influence the pattern of identity. Conflicts related to the construction of houses of worship were triggered by a combination of two things: namely the presence of regulations that were considered discriminatory and restrictive so that nonMuslims found it difficult to obtain permits for the construction of houses of worship; as well as socio-demographic transformation in the community due to births, migration, and diversity of 
sects/denominations which resulted in their need for places of worship increases. The author recommends the importance of the government or related parties to consider the diversity of these social dynamics in every policy formulation that affects the religious life of minority groups in Aceh.

\section{References}

Aceh, BPS. "Propinsi Aceh Dalam Angka Tahun 2010.” Banda Aceh: BPS Aceh, 2010.

Ahmed, Sameera T. "Young British Muslims: Social Space and Active Identity." University of Leicester, 2003.

Alfian, Ibrahim. Sastra Perang: Sebuah Pembicaraan Mengenai Hikayat Perang Sabil. Jakarta: Balai Pustaka, 1992.

Ali-Fauzi, Ihsan, Samsu Rizal Panggabean, Nathanael Gratias Sumaktoyo, H.T. Anick, Husni Mubarak, Testriono, and Siti Nurhayati. Kontroversi Gereja Di Jakarta. Edited by M. Endy Saputro. Yogyakarta: CRCS Universitas Gadjah Mada, 2011.

Ansor, Muhammad. '“Kita Kan Beda!': Persamaan Remaja Perempuan Muslim Dan Kristen Di Langsa, Aceh.” Harmoni 13, no. 2 (2014): 37-50.

—. “Menjadi Seperti Beragama Lain': Jilbab Dan Identitas Hibrid Mahasiswi Kristen Aceh.” Penamas 29, no. 1 (2016): 11-30.

—. "We Are from the Same Ancestors": Christian-Muslim Relations in Contemporary Aceh Singkil." Al-Albab 3, no. 1 (2014): 3-24. https://doi.org/10.24260/alalbab.v3i1.92.

Ansor, Muhammad, and Yaser Amri. "Being Christians in the Acehnese Way: Illiberal Citizenship and Women's Agency in the Islamic Public Sphere." Journal of Indonesian Islam 14, no. 1 (June 1, 2020): 77-112. https://doi.org/10.15642/ JIIS.2020.14.1.77-112. 
——. "Beyond Pious Critical Agency: Women, Interfaith Marriage and Religious Conversion In Aceh." Analisa 1, no. 2 (December 21, 2016): 217-38. https://doi.org/10.18784/analisa.v1i2.368.

Ansor, Muhammad, Yaser Amri, and Ismail Fahmi Arrauf. "Under the Shadow of Sharia: Christian Muslim Relations from Acehnese Christian Experience.” Komunitas 8, no. 1 (2016): 125-34. https://doi.org/10.15294/komunitas.v8i1.4966.

Ansor, Muhammad, and Cut Intan Meutia. "Jilbab Dan Reproduksi Identitas Perempuan Kristen Ruang Publik Sekolah Aceh.” Kawistara 6, no. 2 (2016): 157-74. https://doi.org/10.22146/ kawistara.15561.

Archer, Margaret S. Culture and Agency: The Place of Culture in Social Theory. Cambridge: Cambridge University Press, 1996.

Aritonang,Jan Sihar, and Karel Steenbrink. A History of Christianity in Indonesia. Leiden and Boston: Brill, 2008.

Bakhtin, M.M. Art and Aswerability: Early Philosophical Essays. Edited by Michael Holquist and Vadim Liapunov. Austin: University of Texas Press, 1990.

—. Problems of Dostoevsky's Poetics. Edited by Caryl Emerson. Minneapolis and London: University of Minnesota Press, 1984.

- Rabelais and His World. Bloomington and Indiana Polis: Indiana University Press, 1984.

—. Speech Genres and Other Late Essys. Austin: University of Texas Press, 1986.

—. The Dialogic Imagination: Four Essays. Austin: University of Texas Press, 1981.

Barlas, Asma. "Believing Women"' in Islam: Unreading Patriarchal Interpretations of the Qur'an. Austin: University of Texas Press, 2002. 
—. "Women's Readings of the Qur'an." In The Cambridge Companion to the Qur'an, edited by Jane Dammen McAuliffe, 255-71. Cambridge, New York, Melbourne, Madrid, Cape Town, Singapore, Sao Paulo: Cambridge University Press, 2006.

Bhimji, Fazila. "Identities and Agency in Religious Spheres: A Study of British Muslim Women's Experience." Gender, Place \& Culture: A Journal of Feminist Geography 16, no. 4 (2009): 365-80. https://doi.org/10.1080/09663690903003850.

BPS Aceh Tenggara. “Aceh Tenggara Dalam Angka 2014.” Aceh Tenggara, 2014.

—_. "Kecamatan Lawe Sigala Gala Dalam Angka 2014.” Aceh Tenggara, 2014.

— . "Sensus Penduduk Aceh Tenggara Tahun 2010.” Aceh Tenggara, 2010.

Buehler, Michael, and Dani Muhtada. "Democratization and the Diffusion of Shari'a Law: Comparative Insights from Indonesia." South East Asia Research 24, no. 2 (2016): 261-82. https://doi.org/10.1177/0967828X16649311.

Cattoni, Nadia. "The Figure of Radha in Miniature Paintings: From the Pastoral to the Courtly, from Text to Visuality, from Polyphony to Normativity." Religion \& Gender 5, no. 1 (2015): 52-70. https://doi.org/10.18352/rg.10083.

Chatelard, Geraldine. "The Constitution of Christian Communal Boundaries and Spheres in Jordan." Journal of Church and State 52, no. 3 (2010): 476-502. https://doi.org/10.1093/ jcs/csq079.

Christou, Anastasia. Narratives of Place, Culture and Identity: Second-Generation Greek-Americans Return 'Home.'Amsterdam: Amsterdam University Press, 2006.

Crouch, Melissa. "Implementing the Regulation on Places of Worship in Indonesia: New Problems, Local Politics and 
Court Action.” Asian Studies Review 34, no. 4 (2010): 40319. https://doi.org/10.1080/10357823.2010.527921.

Dilger, Hansjorg. "Healing the Wounds of Modernity: Salvation, Community and Care in a Neo-Pentecostal Church in Dar Es Salaam, Tanzania." Journal of Religion in Africa 37 (2007): 59-83. https://doi.org/10.1163/157006607X166591.

Droeber, Julia. 'We Are Different!' Similarities between Christian and Muslim Women in Jordan." Islam and ChristianMuslim Relations 23, no. 1 (2012): 59-78. https://doi.org/ 10.1080/09596410.2011.634597.

Emmett, Chad F. "The Siting of Churches and Mosques as an Indicator of Christian-Muslim Relations." Islam and ChristianMuslim Relations 20, no. 4 (2009): 451-76. https://doi.org/ 10.1080/09596410903194902.

Fasya, Teuku Kemal. "Memperbaiki Keberagamaan Singkil." Kompas. 2015.

Febriandi, Yogi. "Identitas Tunggal Dan Minoritas Non-Muslim Di Kota Langsa." In Praktik Pengelolaan Keragaman Di Indonesia: Konstruksi Identitas Dan Ekslusi Sosial, edited by Mohammad Iqbal Ahnaf, Trisno Sutanto, Subandri Simbolon, and Azin Anwar Fachrudin, 133-48. Yogyakarta: CRCS Universitas Gadjah Mada, 2018.

—_. "Menyiasati Politik 'Kerukunan Agama' Di Bawah Qanun Aceh.” In Islam, Formalisasi Syariat Islam Dan Post-Islamisme Di Aceh, edited by Miswari, 109-15. Banda Aceh: Bandar Publishing, 2019.

_- "Stuck in Sharia Space: The Experiences of Christian Students to Reside in Langsa, Aceh." Al-Jami'ah: Journal of Islamic Studies 59, no. 1 (2021): 33-56. https://doi.org/ 10.14421/ajis.2021.591.33-56.

- - "There Is No Place for Christians: The Experiences of Christian Students in Getting Access to Residence in Langsa, Aceh.” In Annual International Conference on Islamic Studies XVII, 1-15, 2017. 
Fikri, Mumtazul. "Islamic Shari'a and Religious Freedom on Non-Muslim: Study on Spritual Education in Public Schools in Banda Aceh, Indonesia." Educational Research International 5, no. 1 (2016): 25-31.

Ghorashi, Halleh. "Bringing Polyphony One Step Further: Relational Narratives of Women from the Position of Difference." Women's Studies International Forum 43 (2014): 59-66. https://doi.org/10.1016/j.wsif.2013.07.019.

Giddens, Anthony. Central Problems in Social Theory: Action, Structure and Contradiction in Social Analysis. London: Palgrave Macmillan, 1979.

Grayman, Jesse Hession. "Humanitarian Encounters in PostConflict Aceh, Indonesia.” Harvard University, 2012.

Gregory, Shaun. "Under the Shadow of Islam: The Plight of the Christian Minority in Pakistan." Contemporary South Asia 20, no. 2 (2012): 195-212. https://doi.org/10.1080/ 09584935.2012 .670201 .

Haddad, Mohanna. "Christian Identity in the Jordanian Arab Culture: A Case Study of Two Communities in North Jordan.” Journal of Muslim Minority Affairs 20, no. 1 (2000): 137-46.

Hadi, Amirul. "Aceh and the Portuguese: A Study of the Struggle of Islam in Southeasth Asia, 1500-1579.” McGill University, 1992.

Hoon, Chang-Yau. "Religious Aspirations among Urban Christians in Contemporary Indonesia.” International Sociology 31, no. 4 (2016): 413-31. https://doi.org/10.1177/0268580916643853.

Hoon, Chang-You. "Between Evangelism and Multiculturalism: The Dynamics of Protestant Christianity in Indonesia." Social Compass 60, no. 4 (2013): 457-70.

Husein, Fatimah. Muslim-Christian Relation in the New Order Indonesia: The Exclusivist and Inclusivist Muslims' Perspectives. Bandung: Mizan, 2005. 
Ichwan, Moch Nur, Arskal Salim, and Eka Srimulyani. "Islam and Dormant Citizenship: Soft Religious Ethno-Nationalism and Minorities in Aceh, Indonesia." Islam and ChristianMuslim Relations 31, no. 2 (April 2, 2020): 215-40. https:/ /doi.org/10.1080/09596410.2020.1780407.

Indiyanto, Agus. Agama Di Indonesia Dalam Angka: Dinamika Demografis Berdasarkan Sensus Penduduk Tahun 2000 Dan 2010. Jogyakarta: CRCS Universitas Gadjah Mada, 2013. https://doi.org/978-602-17781-2-8.

Kamp, Linda van de. "Public Counselling: Brazilian Pentecostal Intimate Performances among Urban Women in Mozambique." Culture, Helath and Sexuality 15, no. sup4 (2013): S523-36. https://doi.org/10.1080/13691058.2013.772239.

Klaver, Miranda, Johan Roeland, Peter Versteeg, Hijme Stoffels, and Remco van Mulligen. "God Changes People: Modes of Authentication in Evangelical Conversion Narratives." Journal of Contemporary Religion 32, no. 2 (2017): 23751. https://doi.org/10.1080/13537903.2017.1298905.

Kristeva, Julia. Revolution in Poetic Language. New York: Columbia University Press, 1984.

Listerborn, Carina. "Geographies of the Veil: Violent Encounters in Urban Public Spaces in Malmo, Sweden.” Social \& Cultural Geography16, no. 1 (2015): 95-115. https://doi.org/10.1080/ 14649365.2014.950690.

Lombard, Denys. Kerajaan Aceh Jaman Sultan Iskandar Muda (1607-1636), edited by Winarsih Arifin. Jakarta: Balai Pustaka, 1991.

Lybarger, Loren D. "For Church or Nation? Islamism, SecularNationalism, and the Transformation of Christian Identities in Palestine." Journal of the American Academy of Religion 75, no. 4 (2007): 777-813. https://doi.org/10.1093/jaarel/ $1 \mathrm{fm} 066$. 
Makin, Al. "Islamic Acehnese Identity, Sharia, and Christianization Rumor: A Study of the Narratives of the Attack on the Bethel Church in Penauyong Banda Aceh." Journal of Indonesian Islam 10, no. 01 (2016): 1-36. https://doi.org/ 10.15642/JIIS.2016.10.1.1-36.

Mawardi, Muhammad Suhaili Sufyan, Yusmami, and Azwir. "Identity Negotiation of Christian and Muslim Students in Interaction Between Religions in Langsa.” Miqot 43, no. 2 (2019): 261-77.

Miles, Matthew B., and A. Michael Huberman. An Expanded Sorcebook Qualitative Data Analysis. Thousand Oaks, London New Delhi: Sage Publications, 1994.

Miswar, Khairil. "Misionaris Dan 'Pagar Betis."” serambinews.com, 2015.

Miswari. "Mu'dilat al-'Aqlîyah al-Masîhîyah fî Hudûd Balad alSharî‘ah Al-Islâmîyah.” Studia Islamika 25, no. 2 (2018): 351-403.

Mubarok. Rangkuman Peta Keagamaan Di Indonesia. Jakarta: Departemen Agama Republik Indonesia Badan Proyek Penelitian dan Pengembangan Agama, 1995.

Muhajir, Al Fairusy. "”Karena Klan Dan Marga Kami Berdamai: Model Kerukunan Dan Rekonsiliasi Konflik Antar-Umat Beragama Di Aceh Singkil.” Al-Ijtima': International Journal of Government and Social Science 1, no. 1 (2015): 41-42.

Mujiburrahman. Feeling Threatened: Muslim-Christian Relations in Indonesia's New Order. Leiden: Amsterdam University Press, 2006. https://doi.org/9789053569382.

Pentilla, Maija. "Creating an Evangelical Self: An Analysis of Narratives of Conversion to Evangelicalism in Post-Soviet St Petersburg." Religion, State and Society 44, no. 2 (2016): 111-31. https://doi.org/10.1080/09637494.2016.1175156.

Pype, Katrien. "Dancing for God or the Devil: Pentecostal Discourse 
on Popular Dance in Kinshasa." Journal of Religion in Africa 36, no. 3-4 (2006): 296-318.

Qurtuby, Sumanto Al. “Ambonese Muslim Jihadists, Islamic Identity, and the History of Christian-Muslim Rivarly in the Moluccas, Eastern Indonesia." International Journal of Asian Studies 12, no. 1 (2015): 1-29. https://doi.org/ $: 10.1017 /$ S1479591414000199.

_- . "Interreligious Violence, Civic Peace, and Citizenship: Christian and Muslim in Maluku, Eastern Indonesia." Boston University, 2013.

__ . "Peacebuilding in Indonesia: Christian-Muslim Alliances in Ambon Island." Islam and Christian-Muslim Relations 24,no.3(2013):349-67.https//doi.org/10.1080/09596410.2013.785091.

—_. "Reconciliation from Below: Indonesia's Religious Conflict and Grassroots Agency for Peace.” Peace Research 44/45, no. 2/1 (2013): 135-62.

Rais, Rasul Bakhsh. "Identity Politics and Minorities in Pakistan." South Asia: Journal of South Asian Studies 30, no. 1 (2007): 111-25. https://doi.org/10.1080/00856400701264050.

Reid, Anthony. The Blood of the People: Revolution and the End of Traditional Rule in Northern Sumatra. Oxford, New York, Melbourne, and Kuala Lumpur: Oxford University Press, 1979.

Robbins, Joel. "Pantecostal Networks and the Spirit of Globalization: On the Social Productivity of Ritual Forms." Social Analysis 53, no. 1 (2009): 55-66. https://doi.org/10.3167/sa.2009.530104.

Saefudin, Ahmad, and Fathur Rohman. "Building Social Harmony in the Jepara Shi'ite Minorities." Journal of Contemporary Islam and Muslim Societies 3, no. 2 (December 30, 2019): 49. https://doi.org/10.30821/jcims.v3i2.5622.

Safrilsyah. "Non Muslim Under the Regulation of Islamic Law in Aceh Province." In Annual International Conference on Islamic Studies XII, edited by Nur Kholis and Imas 
Maesaroh, 544-53. Surabaya: IAIN Sunan Ampel Surabaya, 2012.

Salim, Arskal. “'Sharia from below' in Aceh (1930s-1960s): Islamic Identity and the Right to Self Determination with Comparative Reference to the Moro Islamic Liberation Front (MILF)." Indonesia and the Malay World 32, no. 92 (2004): 80-99. https://doi.org/10.1080/1363981042000263471.

Schulzl, Dorothea E. “Mediating Authority: Media Technologies and the Generation of Charismatic Appeal in Southern Mali." Culture and Religion: An Interdisciplinary Journal 16, no.2(2015): 125-45. https://doi.org/10.1080/14755610.2015.1058525.

Scott, Rachel M. The Challenge of Political Islam: Non-Muslims and the Egyptian State. Stanford, California: Stanford University Press, 2010.

Setiawan, Deny, and Bahrul Khoir Amal. "Membangun Pemahaman Multikultural Dan Multiagama Guna Menangkal Radikalisme Di Aceh Singkil." Al-Ulum 16, no. 2 (2016): 348-67.

Shihab, Alwi. Membendung Arus: Respon Gerakan Muhammadiyah Terhadap Penetrasi Misi Kristen Di Indonesia. Bandung: Mizan, 1998.

—. "The Muhammadiyah Movement and Its Controversy with Christian Mission.” Temple University, 1995.

Stolz, Jorg. “"All Things Are Possible': Towards a Sociological Explanation of Pentecostal Miracles and Healings." Sociology of Religion 72, no. 4 (2011): 456-82. https://doi.org/10.1093/ socrel/srr019.

Sulaiman, Teuku Muhammad Jaafar. "Dampak Qanun Terhadap Eksistensi Rumah Ibadah Di Aceh.” In Praktik Pengelolaan Keragaman Di Indonesia: Konstruksi Identitas Dan Ekslusi Sosial, edited by Mohammad Iqbal Ahnaf, Trisno Sutanto, Subandri Simbolon, and Aziz Anwar Fachrudin, 173-86. Yogyakarta: CRCS Universitas Gadjah Mada, 2018. 
—_. "Robohnya Rumah Tuhan Di Negeri Syariat: Perjuangan Hak Beribadah Gereja Bethel Indonesia Di Kota Bandar Wisata Islam.” In Praktik Pengelolaan Keragaman Di Indonesia: Kontestasi Dan Koeksistensi, edited by Mohammad Iqbal Ahnaf, 11-35. Banda Aceh: CRCS Universitas Gadjah Mada, 2015.

Taylor, Reed W. “A Postcolonial Inquiry of Women's Political Agency in Aceh, Indonesia: Towards a Muslim Feminist Approach?” Virginia Polytechnic Institute and State University, 2012.

Tenggara, BPS Aceh. "Kecamatan Babul Makmur Dalam Angka Tahun 2014.” Aceh Tenggara, 2014.

Veer, Paul van 't. Perang Aceh: Kisah Kegagalan Snouck Hurgronje. Jakarta: Grafiti Press, 1985.

Weber, Max. The Protestant Ethic and the Spirit of Capitalism. London and New York: Routledge, 2001.

Wieringa, Edwin. "The Dream of the King and the Holy War against the Dutch: The 'Kôteubah' of the Acehnese Epic, 'Hikayat Prang Gômpeuni.'” Bulletin of the School of Oriental and African Studies, University of London 61, no. 2 (1998): 298-308. 


\section{Endnotes:}

${ }^{1}$ Anastasia Christou, Narratives of Place, Culture and Identity: Second-Generation Greek-Americans Return 'Home' (Amsterdam: Amsterdam University Press, 2006); Rasul Bakhsh Rais, "Identity Politics and Minorities in Pakistan,” South Asia:Journal of South Asian Studies 30, no. 1 (2007): 111-25, https://doi.org/10.1080/00856400701264050.

${ }^{2}$ Sameera T. Ahmed, "Young British Muslims: Social Space and Active Identity" (University of Leicester, 2003); Anthony Giddens, Central Problems in Social Theory: Action, Structure and Contradiction in Social Analysis (London: Palgrave Macmillan, 1979); Margaret S. Archer, Culture and Agency: The Place of Culture in Social Theory (Cambridge: Cambridge University Press, 1996); Ahmad Saefudin and Fathur Rohman, "Building Social Harmony in the Jepara Shi' ite Minorities," Journal of Contemporary Islam and Muslim Societies 3, no. 2 (December 30, 2019): 49, https://doi.org/10.30821/ jcims.v3i2.5622.

${ }^{3}$ Mumtazul Fikri, "Islamic Shari'a and Religious Freedom on Non-Muslim: Study on Spritual Education in Public Schools in Banda Aceh, Indonesia," Educational Research International 5, no. 1 (2016): 25-31; Safrilsyah, "Non Muslim Under the Regulation of Islamic Law in Aceh Province," in Annual International Conference on Islamic Studies XII, ed. Nur Kholis and Imas Maesaroh (Surabaya: IAIN Sunan Ampel Surabaya, 2012), 544-53; Deny Setiawan and Bahrul Khoir Amal, "Membangun Pemahaman Multikultural Dan Multiagama Guna Menangkal Radikalisme Di Aceh Singkil," Al-Ulum 16, no. 2 (2016): 348-67.

${ }^{4}$ Miswari, "Mu'ilat Al-Aqalîyah Al-Masî\%îyah Fî \$udûd Balad Al-Sharî‘ah AlIslâmîyah,” Studia Islamika 25, no. 2 (2018): 351-403.

${ }^{5}$ Safrilsyah, "Non Muslim Under the Regulation of Islamic Law in Aceh Province," in Annual International Conference on Islamic Studies XII, ed. Nur Kholis and Imas Maesaroh (Surabaya: IAIN Sunan Ampel Surabaya, 2012), 544-53.

${ }^{6}$ Mawardi et al., "Identity Negotiation of Christian and Muslim Students in Interaction Between Religions in Langsa," Miqot 43, no. 2 (2019): 261-77.

${ }^{7}$ Michael Buehler and Dani Muhtada, "Democratization and the Diffusion of Shari'a Law: Comparative Insights from Indonesia," South East Asia Research 24, no. 2 (2016): 261-82, https://doi.org/10.1177/0967828X16649311.

${ }^{8} Y o g i$ Febriandi, "Stuck in Sharia Space: The Experiences of Christian Students to Reside in Langsa, Aceh," Al-Jami'ah: Journal of Islamic Studies 59, no. 1 (2021): 33-56, https://doi.org/10.14421/ajis.2021.591.33-56; Muhammad Ansor and Cut Intan Meutia, "Jilbab Dan Reproduksi Identitas Perempuan Kristen Ruang Publik Sekolah Aceh,” Kawistara 6, no. 2 (2016): 157-74, https://doi.org/10.22146/kawistara.15561; Muhammad Ansor, "Kita Kan Beda!': Persamaan Remaja Perempuan Muslim Dan Kristen Di Langsa, Aceh,” Harmoni 13, no. 2 (2014): 37-50; Muhammad Ansor, "'Menjadi Seperti Beragama Lain': Jilbab Dan Identitas Hibrid Mahasiswi Kristen Aceh,” Penamas 29, no. 1 (2016): 11-30; Moch Nur Ichwan, Arskal Salim, and Eka Srimulyani, "Islam and Dormant Citizenship: Soft Religious Ethno-Nationalism 
and Minorities in Aceh, Indonesia," Islam and Christian-Muslim Relations 31, no. 2 (April 2, 2020): 215-40, https://doi.org/10.1080/09596410.2020.1780407.

${ }^{9}$ Fazila Bhimji, "Identities and Agency in Religious Spheres: A Study of British Muslim Women's Experience," Gender, Place \& Culture: A Journal of Feminist Geography 16, no. 4 (2009): 365-80, https://doi.org/10.1080/09663690903003850; Carina Listerborn, "Geographies of the Veil: Violent Encounters in Urban Public Spaces in Malmo, Sweden," Social \& Cultural Geography 16, no. 1 (2015): 95-115, https://doi.org/10.1080/14649365.2014.950690.

${ }^{10}$ Mohanna Haddad, "Christian Identity in the Jordanian Arab Culture: A Case Study of Two Communities in North Jordan," Journal of Muslim Minority Affairs 20, no. 1 (2000): 137-46.

${ }^{11}$ Julia Droeber, "We Are Different!' Similarities between Christian and Muslim Women in Jordan," Islam and Christian-Muslim Relations 23, no. 1 (2012): 59-78, https://doi.org/10.1080/09596410.2011.634597.

${ }^{12}$ Geraldine Chatelard, "The Constitution of Christian Communal Boundaries and Spheres in Jordan," Journal of Church and State 52, no. 3 (2010): 476-502, https://doi.org/10.1093/jcs/csq079.

${ }^{13}$ Loren D. Lybarger, "For Church or Nation? Islamism, Secular-Nationalism, and the Transformation of Christian Identities in Palestine," Journal of the American Academy of Religion 75, no. 4 (2007): 777-813, https://doi.org/10.1093/jaarel/lfm066.

${ }^{14}$ Muhammad Ansor and Yaser Amri, "Beyond Pious Critical Agency: Women, Interfaith Marriage and Religious Conversion In Aceh," Analisa 1, no. 2 (December 21, 2016): 217-38, https://doi.org/10.18784/analisa.v1i2.368; Muhammad Ansor, "We Are from the Same Ancestors": Christian-Muslim Relations in Contemporary Aceh Singkil,"” Al-Albab 3, no. 1 (2014): 3-24, https://doi.org/10.24260/alalbab.v3i1.92; Muhammad Ansor, Yaser Amri, and Ismail Fahmi Arrauf, "Under the Shadow of Sharia: Christian Muslim Relations from Acehnese Christian Experience," Komunitas 8, no. 1 (2016): 125-34, https://doi.org/10.15294/komunitas.v8i1.4966; Muhammad Ansor and Yaser Amri, "Being Christians in the Acehnese Way: Illiberal Citizenship and Women's Agency in the Islamic Public Sphere," Journal of Indonesian Islam 14, no. 1 (June 1, 2020): 77-112, https://doi.org/10.15642/JIIS.2020.14.1.77-112; Ansor and Meutia, "Jilbab Dan Reproduksi Identitas Perempuan Kristen Ruang Publik Sekolah Aceh.”

${ }^{15}$ M.M. Bakhtin, Problems of Dostoevsky's Poetics, ed. Caryl Emerson (Minneapolis and London: University of Minnesota Press, 1984); M.M. Bakhtin, Art and Aswerability: Early Philosophical Essays, ed. Michael Holquist and Vadim Liapunov (Austin: University of Texas Press, 1990); M.M. Bakhtin, The Dialogic Imagination: Four Essays (Austin: University of Texas Press, 1981).

${ }^{16}$ M.M. Bakhtin, Speech Genres and Other Late Essys (Austin: University of Texas Press, 1986); Bakhtin, Problems of Dostoevsky's Poetics.

${ }^{17} \mathrm{Julia}$ Kristeva, Revolution in Poetic Language (New York: Columbia University Press, 1984). 
${ }^{18}$ M.M. Bakhtin, Rabelais and His World (Bloomington and Indiana Polis: Indiana University Press, 1984); Bakhtin, Speech Genres and Other Late Essys.

${ }^{19}$ Asma Barlas, "Believing Women" in Islam: Unreading Patriarchal Interpretations of the Qur'an (Austin: University of Texas Press, 2002); Asma Barlas, "Women's Readings of the Qur'an," in The Cambridge Companion to the Qur'an, ed. Jane Dammen McAuliffe (Cambridge, New York, Melbourne, Madrid, Cape Town, Singapore, Sao Paulo: Cambridge University Press, 2006), 255-71.

${ }^{20}$ Halleh Ghorashi, "Bringing Polyphony One Step Further: Relational Narratives of Women from the Position of Difference," Women's Studies International Forum 43 (2014): 59-66, https://doi.org/10.1016/j.wsif.2013.07.019; Nadia Cattoni, "The Figure of Radha in Miniature Paintings: From the Pastoral to the Courtly, from Text to Visuality, from Polyphony to Normativity," Religion \& Gender 5, no. 1 (2015): 52-70, https://doi.org/10.18352/rg.10083.

${ }^{21}$ Matthew B. Miles and A. Michael Huberman, An Expanded Sorcebook Qualitative Data Analysis (Thousand Oaks, London New Delhi: Sage Publications, 1994).

${ }^{22}$ BPS Aceh, "Propinsi Aceh Dalam Angka Tahun 2010" (Banda Aceh: BPS Aceh, 2010).

${ }^{23}$ Mubarok, Rangkuman Peta Keagamaan Di Indonesia (Jakarta: Departemen Agama Republik Indonesia Badan Proyek Penelitian dan Pengembangan Agama, 1995), 99. 2014).

${ }^{24}$ BPS Aceh Tenggara, “Aceh Tenggara Dalam Angka 2014” (Aceh Tenggara,

${ }^{25}$ BPS Aceh Tenggara, "Kecamatan Babul Makmur Dalam Angka Tahun 2014” (Aceh Tenggara, 2014); BPS Aceh Tenggara, "Sensus Penduduk Aceh Tenggara Tahun 2010" (Aceh Tenggara, 2010); BPS Aceh Tenggara, "Aceh Tenggara Dalam Angka 2014”; BPS Aceh Tenggara, "Kecamatan Lawe Sigala Gala Dalam Angka 2014” (Aceh Tenggara, 2014).

${ }^{26}$ Agus Indiyanto, Agama Di Indonesia Dalam Angka: Dinamika Demografis Berdasarkan Sensus Penduduk Tahun 2000 Dan 2010 (Jogyakarta: CRCS Universitas Gadjah Mada, 2013), https://doi.org/978-602-17781-2-8.

${ }^{27} \mathrm{Al}$ Makin, "Islamic Acehnese Identity, Sharia, and Christianization Rumor: A Study of the Narratives of the Attack on the Bethel Church in Penauyong Banda Aceh,” Journal of Indonesian Islam 10, no. 01 (2016): 1-36, https://doi.org/10.15642/ JIIS.2016.10.1.1-36.

${ }^{28}$ Ansor, "We Are from the Same Ancestors": Christian-Muslim Relations in Contemporary Aceh Singkil,"” 11.

${ }^{29}$ Mujiburrahman, Feeling Threatened: Muslim-Christian Relations in Indonesia's New Order (Leiden: Amsterdam University Press, 2006), https://doi.org/9789053569382.

${ }^{30}$ Chang-Yau Hoon, "Religious Aspirations among Urban Christians in Contemporary Indonesia,” International Sociology 31, no. 4 (2016): 415, https://doi.org/10.1177/ 0268580916643853. 
${ }^{31}$ Fatimah Husein, Muslim-Christian Relation in the New Order Indonesia: The Exclusivist and Inclusivist Muslims' Perspectives (Bandung: Mizan, 2005).

${ }^{32}$ Sumanto Al Qurtuby, "Interreligious Violence, Civic Peace, and Citizenship: Christian and Muslim in Maluku, Eastern Indonesia" (Boston University, 2013); Sumanto Al Qurtuby, "Reconciliation from Below: Indonesia's Religious Conflict and Grassroots Agency for Peace," Peace Research 44/45, no. 2/1 (2013): 135-62; Sumanto Al Qurtuby, "Ambonese Muslim Jihadists, Islamic Identity, and the History of Christian-Muslim Rivarly in the Moluccas, Eastern Indonesia," International Journal of Asian Studies 12, no. 1 (2015): 1-29, https://doi.org/:10.1017/S1479591414000199; Sumanto Al Qurtuby, "Peacebuilding in Indonesia: Christian-Muslim Alliances in Ambon Island," Islam and Christian-Muslim Relations 24, no. 3 (2013): 349-67, https://doi.org/10.1080/09596410.2013.785091.

${ }^{33}$ Ibrahim Alfian, Sastra Perang: Sebuah Pembicaraan Mengenai Hikayat Perang Sabil (Jakarta: Balai Pustaka, 1992); Denys Lombard, Kerajaan Aceh Jaman Sultan Iskandar Muda (1607-1636), ed. Winarsih Arifin (Jakarta: Balai Pustaka, 1991).

${ }^{34}$ Amirul Hadi, "Aceh and the Portuguese: A Study of the Struggle of Islam in Southeasth Asia, 1500-1579" (McGill University, 1992); Anthony Reid, The Blood of the People: Revolution and the End of Traditional Rule in Northern Sumatra (Oxford, New York, Melbourne, and Kuala Lumpur: Oxford University Press, 1979).

${ }^{35}$ Jan Sihar Aritonang and Karel Steenbrink, A History of Christianity in Indonesia (Leiden and Boston: Brill, 2008).

${ }^{36} \mathrm{Hadi}$, "Aceh and the Portuguese: A Study of the Struggle of Islam in Southeasth Asia, 1500-1579.”

${ }^{37}$ Hadi, "Aceh and the Portuguese."

${ }^{38}$ Alfian, Sastra Perang: Sebuah Pembicaraan Mengenai Hikayat Perang Sabil.

${ }^{39}$ Paul van 't Veer, Perang Aceh: Kisah Kegagalan Snouck Hurgronje (Jakarta: Grafiti Press, 1985).

${ }^{40}$ Veer, Perang Aceh.

${ }^{41}$ Edwin Wieringa, "The Dream of the King and the Holy War against the Dutch: The 'Kôteubah' of the Acehnese Epic, 'Hikayat Prang Gômpeuni,'” Bulletin of the School of Oriental and African Studies, University of London 61, no. 2 (1998): 298-308.

${ }^{42}$ Alfian, Sastra Perang: Sebuah Pembicaraan Mengenai Hikayat Perang Sabil.

${ }^{43}$ Arskal Salim, "Sharia from below' in Aceh (1930s-1960s): Islamic Identity and the Right to Self Determination with Comparative Reference to the Moro Islamic Liberation Front (MILF)," Indonesia and the Malay World 32, no. 92 (2004): 80-99, https://doi.org/10.1080/1363981042000263471.

${ }^{44}$ Jesse Hession Grayman, "Humanitarian Encounters in Post-Conflict Aceh, Indonesia” (Harvard University, 2012).

${ }^{45}$ Reed W. Taylor, “A Postcolonial Inquiry of Women's Political Agency in Aceh, Indonesia: Towards a Muslim Feminist Approach?” (Virginia Polytechnic Institute and State University, 2012). 
${ }^{46}$ Khairil Miswar, "Misionaris Dan 'Pagar Betis,”' serambinews.com, 2015.

${ }^{47}$ Taylor, "A Postcolonial Inquiry of Women's Political Agency in Aceh, Indonesia: Towards a Muslim Feminist Approach?"

${ }^{48}$ Alwi Shihab, Membendung Arus: Respon Gerakan Muhammadiyah Terhadap Penetrasi Misi Kristen Di Indonesia (Bandung: Mizan, 1998); Alwi Shihab, "The Muhammadiyah Movement and Its Controversy with Christian Mission” (Temple University, 1995); Ansor and Amri, "Beyond Pious Critical Agency: Women, Interfaith Marriage and Religious Conversion In Aceh."

${ }^{49}$ Ansor, "We Are from the Same Ancestors": Christian-Muslim Relations in Contemporary Aceh Singkil”; Miswari, "Mu'dilat al-'Aqlîyah al-Masîhîyah fî Hudûd Balad al-Sharî‘ah al-Islâmîyah,” Studia Islamika 25, no. 2 (2018): 351; Yogi Febriandi, "There Is No Place for Christians: The Experiences of Christian Students in Getting Access to Residence in Langsa, Aceh," in Annual International Conference on Islamic Studies XVII, 2017, 1-15.

${ }^{50}$ Chang-You Hoon, "Between Evangelism and Multiculturalism: The Dynamics of Protestant Christianity in Indonesia," Social Compass 60, no. 4 (2013): 457-70; Hoon, "Religious Aspirations among Urban Christians in Contemporary Indonesia."

${ }^{51}$ Hoon, "Between Evangelism and Multiculturalism."

${ }^{52} \mathrm{Max}$ Weber, The Protestant Ethic and the Spirit of Capitalism (London and New York: Routledge, 2001).

${ }^{53}$ Maija Pentilla, "Creating an Evangelical Self: An Analysis of Narratives of Conversion to Evangelicalism in Post-Soviet St Petersburg," Religion, State and Society 44, no. 2 (2016): 111-31, https://doi.org/10.1080/09637494.2016.1175156; Miranda Klaver et al., "God Changes People: Modes of Authentication in Evangelical Conversion Narratives," Journal of Contemporary Religion 32, no. 2 (2017): 23751, https://doi.org/10.1080/13537903.2017.1298905.

${ }^{54}$ Aritonang and Steenbrink, A History of Christianity in Indonesia.

${ }^{55}$ Joel Robbins, "Pantecostal Networks and the Spirit of Globalization: On the Social Productivity of Ritual Forms," Social Analysis 53, no. 1 (2009): 55-66, https://doi.org/10.3167/sa.2009.530104.

${ }^{56}$ Hoon, "Between Evangelism and Multiculturalism: The Dynamics of Protestant Christianity in Indonesia."

${ }^{57}$ Hoon, "Religious Aspirations among Urban Christians in Contemporary Indonesia."

${ }^{58}$ Yogi Febriandi, "Identitas Tunggal Dan Minoritas Non-Muslim Di Kota Langsa," in Praktik Pengelolaan Keragaman Di Indonesia: Konstruksi Identitas Dan Ekslusi Sosial, ed. Mohammad Iqbal Ahnaf et al. (Yogyakarta: CRCS Universitas Gadjah Mada, 2018), 133-48.

${ }^{59}$ Makin, "Islamic Acehnese Identity, Sharia, and Christianization Rumor: A Study of the Narratives of the Attack on the Bethel Church in Penauyong Banda Aceh." 
${ }^{60}$ Hoon, "Between Evangelism and Multiculturalism: The Dynamics of Protestant Christianity in Indonesia."

${ }^{61}$ Jorg Stolz, "'All Things Are Possible': Towards a Sociological Explanation of Pentecostal Miracles and Healings," Sociology of Religion 72, no. 4 (2011): 45682, https://doi.org/10.1093/socrel/srr019; Hansjorg Dilger, "Healing the Wounds of Modernity: Salvation, Community and Care in a Neo-Pentecostal Church in Dar Es Salaam, Tanzania," Journal of Religion in Africa 37 (2007): 59-83, https://doi.org/ 10.1163/157006607X166591.

${ }^{62}$ Katrien Pype, "Dancing for God or the Devil: Pentecostal Discourse on Popular Dance in Kinshasa," Journal of Religion in Africa 36, no. 3-4 (2006): 296318.

${ }^{63}$ Linda van de Kamp, "Public Counselling: Brazilian Pentecostal Intimate Performances among Urban Women in Mozambique," Culture, Helath and Sexuality 15, no. sup4 (2013): S523-36, https://doi.org/10.1080/13691058.2013.772239.

${ }^{64}$ Dorothea E. Schulzl, "Mediating Authority: Media Technologies and the Generation of Charismatic Appeal in Southern Mali," Culture and Religion: An Interdisciplinary Journal16, no. 2(2015): 125-45, https:/doi.org/10.1080/14755610.2015.1058525.

${ }^{65}$ Rachel M. Scott, The Challenge of Political Islam: Non-Muslims and the Egyptian State (Stanford, California: Stanford University Press, 2010); Chad F. Emmett, "The Siting of Churches and Mosques as an Indicator of Christian-Muslim Relations," Islam and Christian-Muslim Relations 20, no. 4 (2009): 451-76, https://doi.org/ 10.1080/09596410903194902; Shaun Gregory, "Under the Shadow of Islam: The Plight of the Christian Minority in Pakistan," Contemporary South Asia 20, no. 2 (2012): 195-212, https://doi.org/10.1080/09584935.2012.670201.

${ }^{66}$ Melissa Crouch, "Implementing the Regulation on Places of Worship in Indonesia: New Problems, Local Politics and Court Action," Asian Studies Review 34, no. 4 (2010): 403-19, https://doi.org/10.1080/10357823.2010.527921.

${ }^{67}$ Yogi Febriandi, “Menyiasati Politik 'Kerukunan Agama' Di Bawah Qanun Aceh," in Islam, Formalisasi Syariat Islam Dan Post-Islamisme Di Aceh, ed. Miswari (Banda Aceh: Bandar Publishing, 2019), 109-15; Teuku Muhammad Jaafar Sulaiman, "Dampak Qanun Terhadap Eksistensi Rumah Ibadah Di Aceh," in Praktik Pengelolaan Keragaman Di Indonesia: Konstruksi Identitas Dan Ekslusi Sosial, ed. Mohammad Iqbal Ahnaf et al. (Yogyakarta: CRCS Universitas Gadjah Mada, 2018), 173-86.

${ }^{68}$ Ihsan Ali-Fauzi et al., Kontroversi Gereja Di Jakarta, ed. M. Endy Saputro (Yogyakarta: CRCS Universitas Gadjah Mada, 2011); Teuku Muhammad Jaafar Sulaiman, "Robohnya Rumah Tuhan Di Negeri Syariat: Perjuangan Hak Beribadah Gereja Bethel Indonesia Di Kota Bandar Wisata Islam," in Praktik Pengelolaan Keragaman Di Indonesia: Kontestasi Dan Koeksistensi, ed. Mohammad Iqbal Ahnaf (Banda Aceh: CRCS Universitas Gadjah Mada, 2015), 11-35; Miswari, "Mu'dilat al-'Aqlîyah al-Masîhîyah fî Hudûd Balad al-Sharî‘ah al-Islâmîyah.”

${ }^{69}$ Deny Setiawan and Bahrul Khoir Amal, "Membangun Pemahaman Multikultural Dan Multiagama Guna Menangkal Radikalisme Di Aceh Singkil,” Al-Ulum 16, no. 
2 (2016): 348-67; Al Fairusy Muhajir, "Karena Klan Dan Marga Kami Berdamai: Model Kerukunan Dan Rekonsiliasi Konflik Antar-Umat Beragama Di Aceh Singkil," Al-Ijtima': International Journal of Government and Social Science 1, no. 1 (2015): 41-42; Teuku Kemal Fasya, "Memperbaiki Keberagamaan Singkil," Kompas, 2015; Ansor, "We Are from the Same Ancestors": Christian-Muslim Relations in Contemporary Aceh Singkil."” 